\title{
TIPP 2 DIYYABETLİ HASTALARIN SAĞLIK İNANCI, HASTALIK TUTUMLARI VE METABOLİK KONTROLÜNÜN DEĞERLENDİRİLMESİ
}

\author{
Evaluation of Health Belıefs, Attitudes towards Illness and Metabolic Control Variables of \\ Patients with Type 2 Diabetes
}

\author{
Selin YAĞCI ${ }^{1}$, Elanur YILMAZ KARABULUTLU ${ }^{1}$ \\ ${ }^{1}$ Atatürk Üniversitesi, Hemşirelik Fakültesi, İ̧̧ Hastalıkları Hemşireliği, ERZURUM, TÜRKIYYE
}

\begin{abstract}
ÖZ ABSTRACT

Amaç: Tip 2 Diyabetli hastaların sağlık inancı, hastalık Objective: This study aims to determine health beliefs, attitudes tutumları ve metabolik kontrolünü belirlemek ve bu değişkenler towards illness and metabolic control of patients with Type 2 arasındaki ilişkiyi incelemek amacıyla yapıldı. diabetes as well as investigating the relationship between these

Gereç ve Yöntem: Tanımlayıcı türde olan araştırma Temmuz variables.
\end{abstract}

2014-Ocak 2017 tarihleri arasında yürütüldü. Araştırma Material and Methods: This descriptive study was conducted örneklemini araştırmaya alınma kriterlerine uyan 271 Tip 2 between July, 2014 and January 2017. The study sample consisted of diyabet hastası oluşturdu. Verilerin toplanmasında Tanıtıcı Bilgi 271 patients with Type 2 diabetes who met the research inclusion Formu, Metabolik Kontrol Sonuçları, Sağlı İnanç Modeli criteria. The Information Form, Metabolic Control Results, Health Ölçeği ve Diyabet Tutum Ölçeği kullanıldı.

Belief Model Scale, and Diabetes Attitude Scale were used for data

Bulgular: Diyabetli hastaların algılanan ciddiyet, algılanan collection.

yararlar, sağlıkla ilgili aktiviteler alt boyutlarında ve toplam Results: It was found that patients with diabetes had positive health sağlık inancında pozitif sağlık inancına ( $>4)$ sahip oldukları beliefs in the perceived severity, perceived benefits, health-related tespit edildi. Hastaların en yüksek diyabet tutumu puan activities sub-scales and positive total health beliefs (Score >4). ortalamasını diyabetin ciddiyeti alt boyutundan $(3.07 \pm 0.70)$ ve Patients were found to have the highest mean score in the diabetic en düşük puan ortalamasını ise özel eğitim gereksinimi alt severity sub-scale $(3.07 \pm 0.70)$, and the lowest mean score in the

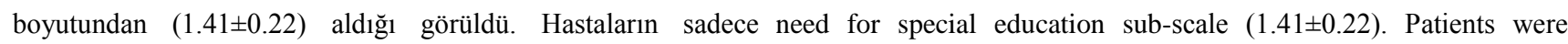
diyabetin ciddiyeti alt boyutunda pozitif tutuma (>3) sahip found to have a positive attitude (Score $>3$ ) only in the diabetic oldukları saptandı. Hastaların SIMÖ toplam puan ortalamaları ile severity sub-scale. A statistically significant and negative correlation kalça çevresi ortalaması arasında negatif ve HDL oranları was found between the mean hip circumference and the total Health arasında pozitif, DTÖ toplam puan ortalamaları ile trigliserit Belief Model Scale scores of the patients $(\mathrm{p}<0.05)$. There was a düzeyi ortalamaları arasında ise pozitif bir ilişki bulundu significant positive correlation between the mean Diabetes Attitude $(\mathrm{p}<0.05)$.

Scale scores and triglyceride levels of patients $(\mathrm{p}<0.05)$.

Sonuç: Araştırmada Tip 2 diyabetlilerin genel olarak sağlık Conclusion: In the study, patients with Type 2 diabetes were inanc1 pozitif, diyabet tutumları ise negatif olarak generally found to have positive health beliefs, and negative attitudes değerlendirildi. Hastaların sağlık inancı ve diyabet tutumlarının towards diabetes. Patients' health beliefs and diabetes attitudes were bazı metabolik kontrol değişkenlerini etkilediği belirlendi.

found to affect some metabolic control variables.

Anahtar Kelimeler: Diyabet, sağlık inancı, tutum

Keywords: Diabetes, health belief, attitude 


\section{GíRiş}

Diyabet yaşam süresini kısaltan, yaşam kalitesini düşüren, birey ve toplum açısından ciddi ekonomik kayıplara yol açan, kişilerin mesleki ve sosyal yaşantısını olumsuz yönde etkileyen önemli bir hastalıktır. Dünyadaki nüfus artışı, şehirleşme, ileri yaş, obezitenin artması, fiziksel aktivitenin azalması ile birlikte Tip 2 diyabet prevelansı hızla artmaktadır (1). Uluslararası Diyabet Federasyonu (IDF) verilerine göre dünyada 2015 yılı itibariyle 415 milyon diyabet hastasının olduğu ve bu oranın 2040 yılında 642 milyon insana ulaşacağı beklenmektedir (2). Ülkemizde ise Türkiye Diyabet Epidemiyolojisi Çalışması II' ye (TÜRDEP II) göre 6.9 milyon diyabet hastasının var olduğu tespit edilmiştir (3). Kronik bir hastalık olan diyabet bireyin yaşam süresi boyunca devam etmekte ve hastalığın iyi yönetilememesi zaman içerisinde komplikasyonların da ortaya çıkmasına neden olmaktadır. Bu komplikasyonlar hem ölüme yol açabilmekte hem de hastaların yaşam kalitesini bozmaktadır. Diyabet tedavisi bireyin yaşam boyu devam etmesini, tedaviyi kendisinin yönetmesini ve yaşam değişikliği yapmasını gerektirir (2). Diyabet yönetimi için bireylerde sağlıklı yaşam biçimi davranışları geliştirmek bu nedenlerle çok önemlidir.

Kişilerin kendi sağlığı ya da hastalıklarıyla ilgili inanç ve tutumları hastalığıyla ilgili yaşam biçimi düzenlemelerine aktif katılımını sağlamaktadır (4). Sağlık İnanç Modeli' ne (SİM) göre hastanın sağlığını korumaya yönelik davranışları gerçekleştirmesinde bireysel inançların rolü bulunmaktadır. Bu model bir hastalıktan kaçınmanın ya da sağlıklı olmanın kişi açısından değeri ve o kişinin belirli bir davranışının hastalığg önleme ya da sağlığı iyileştirmeye yol açacağ1 beklentisi üzerine kurulmuştur (5). Diyabetlilerin sağlık inanç ve tutumlarının hastalığına yönelik uyumlu davranışları sergilemesinde önemli olduğu tespit edilmiştir (6). Diyabetli hastaların sağlık ve hastalıklarıyla ilgili sergiledikleri tutum ve davranışları diyabet tedavisinin yapısını oluşturur ve bakımı önemli derecede etkiler. Diyabet yönetiminin gerçekleştirilebilmesi, hastanın diyabetle ilgili aldığ1 bilgiyi davranışa dönüştürebilmesi ve sahip olduğu olumlu tutumlarla ilişkilidir. $\mathrm{Bu}$ nedenle diyabetli bireylerin tutumları ve yanlış olan inançları değerlendirilmelidir. Yanlış inançlar bilinirse davranışa dönüştürülmeden önce düzeltilebilir ve hastalığa karşı tutumunu ve uyumunu kolaylaştırılabilir. Diyabetli hastalığı ile ilgili olumlu tutum sergilerse metabolik kontrolün normal değerlere daha kolay ulaşmasını sağlayabilir. (7). Yapılan çalışmalarda, diyabetik hastaların metabolik kontrolü ile diyabet tutumu arasında anlamlı bir ilişki olduğu, HbA1C'si ve kan basıncı yüksek olan hastaların genel diyabet tutumunun olumsuz, öz-bakım ve diyete uyumlarının kötü olduğu tespit edilmiştir (7-9).

Bu araştırma Tip 2 Diyabetli hastaların sağlık inancını, hastalık tutumlarını ve metabolik kontrolünü belirlemek ve bu değişkenler arasındaki ilişkiyi incelemek amacıyla yapılmıştır.

\section{GEREÇ VE YÖNTEM}

Araştırmanın etik açıdan uygunluğunun değerlendirilmesi amacıyla Atatürk Üniversitesi Sağlık Bilimleri Fakültesi Etik Kurulu'ndan 16.06.2014 tarihli etik kurul onayı ve araştırmanın yapıldığı hastaneden 04.07.2014 tarihli resmi izinler alınmıştır.

Tanımlayıcı ve ilişki arayıcı tipte yapılan bu araştırmanın verileri Mersin Toros Devlet Hastanesinde toplanmıştır. Araştırmanın evrenini, Mersin Toros Devlet Hastanesi Dahiliye Polikliniğine kontrol amacıyla başvuran ve Dahiliye Servisinde yatarak tedavi gören Tip 2 Diyabet hastaları oluşturmuştur. Örneklem grubuna Temmuz-Ekim 2014 tarihleri arasında hastaneye başvuran, araştırmaya alınma kriterlerine uyan 271 hasta alınmıştır. Araştırmaya alınma kriterleri; en az 6 ay veya daha uzun süredir diyabet tanısı almak, konuşma ve duyu kaybı olmamak, psikiyatrik bir tanı almamış olmak ve 18 yaş ve üstü olmaktır. Araştırmanın verileri Tanıtıcı Bilgi Formu, Metabolik Kontrol Sonuçları Formu, Sağlık İnanç 
Modeli Ölçeği ve Diyabet Tutum Ölçeği kullanılarak toplanmıştır.

\section{Tanıtıcı Bilgi Formu}

$\mathrm{Bu}$ formda sosyo-demografik özellikleri (yaş, cinsiyet, vb.) ve diyabete ilişkin özellikleri (hastalık süresi, tedavi şekli, kontrol sıklığı, vb.) yansıtan sorular yer almaktadır.

\section{Metabolik Kontrol Sonuçları Formu}

Açlık kan şekeri (AKŞ), tokluk kan şekeri (TKŞ), Hemoglobin A1C (HbA1C), beden kitle indeksi (BKI), kan basıncı ölçümü, bel ve kalça çevresi ölçümü, trigliserit, HDL, LDL ve total kolestrol değerleridir.

\section{Sağlık İnanç Modeli Öıçeği (SIMMÖ)}

Sağlık İnanç Modeli Ölçeği, 1994 yllında Schwab ve ark. geliştirdiği Sağlık İnanç Modelinin 5 alt boyutu baz alınarak; Tan tarafindan, diyabetli bireylerin hastalığa ilişkin sağlık inanç, tutum ve sağlık davranışlarını değerlendirmek amacıyla 2004 yılında geliştirilmiştir (10). Ölçeğin diyabet hastaları için geçerlik ve güvenirlik çalışması Kartal ve Özsoy (2007) tarafından yapılmıştır (4). Ölçek 5 alt boyuttan ve toplam 36 maddeden meydana gelmiştir. SİMÖ, algılanan duyarlılık, algılanan ciddiyet, algılanan yararlar, algılanan engeller, sağlıkla ilgili önerilen aktiviteler olmak üzere belirlenmiştir. Ölçek alt boyutları birbirinden bağımsız olup, her alt boyutun toplam puanı o alt boyuttaki madde sayısina bölünerek o alt boyuta ilişkin puan hesaplanmaktadır. Ölçekten alınan puan $\geq 4$ ise pozitif sağlı inancını, $<4$ ise negatif sağlık inancına işaret etmektedir. Genel ölçek Cronbach alfa katsayısı 0.89 olarak hesaplanmıştır (4). $\mathrm{Bu}$ çalışmada ölçeğin Cronbach alfa katsayısı 0.70 olarak hesaplanmıştır.

\section{Diyabet Tutum Ölçeği (DTÖ)}

Amerika'da Ulusal Diyabet Komisyonu tarafindan geliştirilen DTÖ'nün ülkemizde geçerlik ve güvenirlik çalışması Özcan tarafından yapılmıştır (11). DTÖ; özel eğitim gereksinimi, hasta uyumuna karşı tutum, tip 2 diyabetin ciddiyeti, kan glikoz kontrolü ve komplikasyonları, diyabetin hastanın yaşamına etkisi, hasta otonomisine karşı tutum ve ekip bakımına karşı tutumu olmak üzere 7 alt gruptan meydana gelmektedir. Yalnızca diyabetli birey tutumlarını değil aynı zamanda diyabet bakım ekibinin de tutumunun değerlendirilmesine katkıda bulunan ölçüm aracıdır. DTÖ diyabet eğitim programlarının etkisini, eğitimin etkinliğinde hasta tutumunun önemini ve tutum ile davranış arasındaki ilişkiyi açıklamak için kullanılmaktadır. Ölçek maddeleri 1'den 5'e kadar değişen, likert tipi puanlama ile puanlanmaktadır. Puan $>3$ ise pozitif tutum, puan $\leq 3$ ise negatif tutumu belirtmekte olup puanın artışı veya düşüşü o yöndeki tutumu kuvvetlendirmektedir. DTÖ'nün her bir alt grubu oluşturan tüm madde puanlarının toplanarak alt grup madde sayısına bölünmesi ile bireyin o alt gruba ait tutum puanını göstermektedir. Genel olarak diyabet tutum puanı ise ölçekteki tüm maddelerin puanlarının toplanarak 34'e bölünmesi ile hesaplanmaktadır. Genel ölçek cronbach alpha katsayısı ise 0.70 'dir (11). Bu çalışma için Cronbach alfa katsayısı 0.64 bulunmuştur. Veriler araştırmacı tarafından birebir görüşme yöntemi kullanılarak toplanmıştır. Hastaların metabolik kontrol sonuçlarına hastane laboratuvar sonuçlarından ulaşılmıştır. Hastaların boyu, kilosu, bel ve kalça çevresi araştırmacı tarafindan ölçülmüştür. Hastalarla görüşmeler hasta odasında ve diyabet eğitim odasında yapılmıştır.

\section{İstatistiksel analiz}

İstatistiksel analiz, SPSS 19.0 paket programında yapılmıştır. Verilerin değerlendirilmesi yüzdelik, student $\mathrm{t}$ testi, Kruskal-Wallis testi, Mann-Whitney U testi ve korelasyon analizi ile yapılmıştır. Sonuçlar $\% 95$ güven aralı̆̆ında $\mathrm{p}<0.05$ anlamlılık düzeyinde değerlendirilmiştir.

\section{BULGULAR}

Diyabetli hastaların tanıtıcı özelliklerine incelendiğinde; hastaların yaş ortalaması $62.19 \pm 11.18$ olup, \%63.8'i kadın ve \%79'u evli idi. Hastaların $\% 53.1$ 'inin okuma yazmasının olmadığ ve \%87.5'inin 
çalışmadığg tespit edildi. Tip 2 diyabet hastalığına sahip olma süre ortalaması $9.8 \pm 6.8$ yıl olduğu belirlendi. Hastaların \%48.7'sinin insülin tedavisi kullandığ 1 , \%79.7'sinin kan şekerini düzenli olarak ölçtüğü, \%25.1'inin sadece kendini rahatsız hissettiğinde kan şekerine ölçtüğü belirlendi. Hastaların \%93.4'ünün ilaçlarını düzenli kullandığı, \%83.4'ünün düzenli doktor kontrolüne gittiğini ifade ettiği belirlendi. Hastaların \%81.5'inin başka hastalığa sahip olduğu, \%94.5'inin ailesinde diyabet hastalığ1 bulunduğu, \%79'unun egzersiz yapmadığı, \%62.7'sinin beslenme tedavisine uymadiğ 1 ve \%85.2'sinin sigara kullanmadığını ifade ettiği belirlendi. Hastaların kronik komplikasyon dağılımı incelendiğinde, \%11.8'inde diyabetik retinopati, \%24.7'sinde diyabetik nöropati, \%38.7'sinde iskemik kalp hastalığı/geçirilmiş miyokart infartüsü ve \%75.6'sında ise hipertansiyon olduğu belirlendi. Hastalarının \%93 ünde ayak yarası olmadığı belirlendi. Hastaların \%79.3'ü hastalıkla ilgili bilgi aldığını ifade etti.

Metabolik kontrol sonuçları değerlendirildiğinde; AKŞ ortalaması $216.8 \pm 58.2 \mathrm{mg} / \mathrm{dl}$, TKŞ ortalamas1 $217 \pm 45.1 \mathrm{mg} / \mathrm{dl}, \mathrm{HbA1C}$ ortalamas1 \%9.2 \pm 2.2 , BKI ortalamas1 $32.8 \pm 36.5 \mathrm{~kg} / \mathrm{m}^{2}$, sistolik kan basınc1 ortalaması $13.8 \pm 11.5 \mathrm{mmHg}$, diyastolik kan basıncı ortalaması $9.6 \pm 11.8 \mathrm{mmHg}$, bel çevresi ortalaması $96.6 \pm 12.1 \mathrm{~cm}$, kalça çevresi ortalaması $107.4 \pm 12.5 \mathrm{~cm}$, trigliserit ortalamas $206.9 \pm 186 \mathrm{mg} / \mathrm{dl}$, HDL ortalaması $41.7 \pm 17.4 \mathrm{mg} / \mathrm{dl}$, LDL ortalamas1 $132 \pm 70.1 \mathrm{mg} / \mathrm{dl}$, kolestrol ortalaması $198 \pm 47.9 \mathrm{mg} / \mathrm{dl}$ olarak belirlendi (Tablo 1).

Hastaların SİMÖ puan ortalamalarına bakıldığında; en yüksek puan ortalaması algılanan ciddiyet (4.2 \pm 0.3$)$ ve sağlıkla ilgili önerilen aktiviteler $(4.2 \pm 0.2)$ alt boyutunda bulundu. En düşük puan ortalaması ise algilanan duyarlılık alt boyutundan $(2.9 \pm 2.5)$ alınd1. Hastaların algılanan ciddiyet, algılanan yararlar, sağlıkla ilgili aktiviteler alt boyutlarında ve toplam sağlık inancında pozitif sağlık inancına ( $>4)$, algılanan duyarlılık ve algilanan engeller alt boyutlarında ise negatif sağlık inancına $(<4)$ sahip oldukları tespit edildi (Tablo 2).

Tablo 1. Hastaların Metabolik Kontrol Değişkenleri Ortalamaları

\begin{tabular}{lc}
\hline Metabolik Kontrol Değişkenleri & $\mathbf{X} \pm \mathbf{S S}$ \\
\hline Açlık kan şekeri (mg/dl) & $216.8 \pm 58.2$ \\
Tokluk kan şekeri (mg/dl) & $217.0 \pm 45.1$ \\
Hemoglobin A1C (\%) & $9.2 \pm 2.2$ \\
Beden kitle indeksi (kg/m2) & $32.8 \pm 36.5$ \\
Sistolik kan basıncı (mmHg) & $13.8 \pm 11.5$ \\
Diyastolik kan basıncı (mmHg) & $9.6 \pm 11.8$ \\
Bel çevresi (cm) & $96.6 \pm 12.1$ \\
Kalça çevresi (cm) & $107.4 \pm 12.5$ \\
Trigliserit (mg/dl) & $206.9 \pm 186$ \\
Yüksek yoğunluklu lipoprotein (mg/dl) & $41.7 \pm 17.4$ \\
Düşük yoğunluklu lipoprotein (mg/dl) & $132 \pm 70.1$ \\
Total kolestrol (mg/dl) & $198 \pm 47.9$ \\
\hline
\end{tabular}

DTÖ puanları incelendiğinde; hastaların en yüksek puan ortalamasını diyabetin ciddiyeti alt boyutundan (3.07 \pm 0.70$)$ aldığ 1 tespit edildi. Hastaların diyabet tutum ölçeği alt boyutlarında en düşük puan ortalamasını özel eğitim gereksinimi $1.41 \pm 0.22$ alt boyutundan aldığı tespit edildi (Tablo 2). Hastaların diyabetin ciddiyeti alt boyutu hariç toplam ve diğer alt boyutlarda negatif tutuma $(<3)$ sahip oldukları belirlendi (Tablo 2).

Hastaların SİMÖ toplam puanları ve metabolik kontrol değişkenleri arasındaki ilişki incelendiğine; hastaların kalça çevresi ortalaması ile SİMÖ toplam puanları arasında negatif yönde istatistiksel olarak anlamlı bir ilişki olduğu tespit edildi (r:-0.177 p<0.05). Hastaların HDL ortalaması ile SİMÖ toplam puanları arasında pozitif yönde istatistiksel olarak anlamlı bir ilişki olduğu belirlendi (r:0.560 p<0.001). Diğer metabolik kontrol değişkenleri ortalamaları ile SIMÖ toplam puan ortalamaları arasında istatistiksel olarak anlamlı bir ilişki olmadığı bulundu ( $\mathrm{p}>0.05)$ (Tablo 3$)$. 
Araştırma kapsamına alınan diyabetli hastaların DTÖ puan ortalamaları ile trigliserit ortalamaları arasında pozitif yönde anlamlı bir ilişki bulundu (r:0.186, $\mathrm{p}<0.05$ ) (Tablo 3). DTÖ puan ortalamaları ile diğer metabolik kontrol değişkenleri ortalamaları arasında istatistiksel olarak anlamlı bir ilişki olmadığı tespit edildi ( $\mathrm{p}>0.05)$.

Tablo 2. Hastaların SìMÖ ve DTÖ’den Aldıkları Puanların Dağılımı

\begin{tabular}{llc}
\hline Ölçekler & $\mathrm{X} \pm \mathrm{SS}$ & Min-Max \\
\hline SİMÖ & & $2.6-3.2$ \\
Algılanan duyarlılık & $2.9 \pm 2.5$ & $4.1-4.2$ \\
Algılanan ciddiyet & $4.2 \pm 0.3$ & $4.0-4.2$ \\
Algılanan yararlar & $4.1 \pm 0.3$ & $3.2-3.3$ \\
Algılanan engeller & $3.3 \pm 0.3$ & $4.1-4.2$ \\
Sağlıkla ilgili önerilen aktiviteler & $4.2 \pm 0.2$ & $4.0-4.1$ \\
Sağlık inanç toplam & $4.0 \pm 0.4$ & $1.38-1.43$ \\
\hline DTÖ & & $2.03-2.08$ \\
Özel eğitim gereksinimi & $1.41 \pm 0.22$ & $2.98-3.15$ \\
Hasta uyumuna karşı tutum & $2.05 \pm 0.23$ & $2.08-2.14$ \\
Diyabetin ciddiyeti & $3.07 \pm 0.70$ & $2.62-2.73$ \\
Kan glukoz kontrolü ve komplikasyonlar & $2.11 \pm 0.26$ & $1.40-1.46$ \\
Hasta yaşamına diyabetin etkisi & $2.67 \pm 0.45$ & $2.10-2.15$ \\
Hasta otonomisine karşı tutum & $1.43 \pm 0.26$ & $2.01-2.04$ \\
Ekip bakımına karşı tutum & $2.13 \pm 0.20$ & $2.02 \pm 0.15$ \\
Diyabet tutumu toplam & & \\
\hline
\end{tabular}

Tablo 3. Hastaların SİMÖ ve DTÖ ortalamaları ile Metabolik Kontrol Değişkenleri Ortalamaları Arasındaki İlişki

\begin{tabular}{lcccc}
\hline Metabolik kontrol değişkenleri & \multicolumn{2}{c}{ SiMÖ Toplam } & \multicolumn{2}{c}{ DTÖ Toplam } \\
\hline & $\mathrm{r}$ & $\mathrm{p}$ & $\mathrm{r}$ & $\mathrm{p}$ \\
Açlık kan şekeri (mg/dl) & -0.45 & 0.462 & -0.055 & 0.368 \\
Tokluk kan şekeri (mg/dl) & 0.032 & 0.600 & -0.009 & 0.885 \\
Hemoglobin A1C (\%) & 0.012 & 0.846 & -0.088 & 0.151 \\
Beden kitle indeksi (kg/m2) & -0.51 & 0.407 & 0.085 & 0.163 \\
Sistolik kan basınc1 (mmHg) & 0.006 & 0.916 & 0.004 & 0.953 \\
Diyastolik kan basıncı (mmHg) & -0.040 & 0.512 & 0.040 & 0.508 \\
Bel çevresi (cm) & -0.112 & 0.067 & 0.077 & 0.203 \\
Kalça çevresi (cm) & -0.177 & 0.003 & 0.072 & 0.240 \\
Trigliserit (mg/dl) & -0.036 & 0.551 & 0.186 & 0.002 \\
Yüksek yoğunluklu lipoprotein (mg/dl) & 0.560 & 0.000 & 0.007 & 0.910 \\
Düşük yoğunluklu lipoprotein (mg/dl) & -0.106 & 0.081 & 0.025 & 0.687 \\
Total kolestrol (mg/dl) & -0.045 & 0.464 & 0.002 & 0.979 \\
\hline
\end{tabular}




\section{TARTIŞMA}

Çalışmadan elde edilen bulgular ilgili literatür ışı̆ğında tartışılmıştır. Hastaların büyük bir kısmının diyabete bağl1 komplikasyonlara sahip olduğu görülmektedir (\%11.8 diyabetik retinopati, \%24 diyabetik nöropati, \%38.7 iskemik kalp hastalığı/geçirilmiş miyokart infartüsü ve \%75.6 hipertansiyon) olduğu belirlendi. İskemik kalp hastalı̆ğ ve miyokart infartüsü gibi hastalıklar diyabetlilerde en önemli morbidite ve mortalite nedenlerindendir. Özellikle alt ekstremiteleri tutan distal-simetrik duyusal polinöropati, infeksiyon ve iskemi ile birlikte en önemli ayak ampütasyonu, retinopati ise erişkin yaştaki diyabetli hastalarda en önemli körlük nedenidir (12). Bu nedenlerle diyabetik hastaların sağlık inançlarının arttırılması ve olumlu tutumların geliştirilmesi ile komplikasyonların azaltılması hedeflenmelidir.

American Diabetes Association Standards of Medical Care in Diabetes-2017 ve Türk Metabolizma Derneği Diabetes Mellitus ve Komplikasyonlarının Tanı, Tedavi ve İzlem Kılavuzu-2017' de glisemik kontrol hedefleri AKŞ değeri 80-130 mg/dl, TKŞ $<160 \mathrm{mg} / \mathrm{dl}$ ve $\mathrm{HbA1C}<\% 7$ olarak belirtilmiştir. Klavuzda kan basınc1 $<140 / 90 \mathrm{mmHg}$, BKI $<25 \mathrm{~kg} / \mathrm{m} 2$, bel çevresi kadınlarda $>88 \mathrm{~cm}$, erkeklerde $>102 \mathrm{~cm}$ dir. Lipid profili hedef düzeyleri ise trigliserid $<150 \mathrm{mg} / \mathrm{dl}, \mathrm{HDL}$ kolesterol (kadın) $>50 \mathrm{mg} / \mathrm{dl}$, HDL kolesterol (erkek) $>40 \mathrm{mg} / \mathrm{dl}$ ve LDL kolesterol<100 $\mathrm{mg} / \mathrm{dl}$ olarak belirlenmiştir $(12,13)$. Buna göre araştırmaya katılan hastaların AKŞ, TKŞ, HgAlc, BKI, bel çevresi ortalama değerlerinin hedeflenen değerlerden yüksek olduğu gözlenmiştir. Kan basıncı ortalaması bulgularının hedef değere yakın olduğu, HDL kolesterol düzeyinin hedeflenen değerden daha düşük, LDL kolesterol ve trigliserid düzeylerinin ise daha yüksek olduğu belirlenmiştir. Diyabetlilerin \%33-49' unda glisemik kontrol, kan basinc1 ve kolesterol kontrolünün sağlanamadığı ve hastaların yalnızca \%14'ünün bu önemli üç hedefi sağladığı bildirilmiştir (14). $\mathrm{Bu}$ sonuçlar araştırma kapsamına alınan diyabetlilerin metabolik kontrol değerlerinin iyi kontrol düzeyinde olmadığını ve diyabet yönetimi konusunda daha fazla desteklenmesi gerektiğini göstermektedir.

Literatürde diyabet hastalarının sağlığını iyileştirmek ve olumlu sağlık davranışlarını benimsettirmek için, bu hastaların sağlık inançları ve tutumlarının değerlendirilmesi gerektiği vurgulanmaktadır $(9,11,15) . \mathrm{Bu}$ araştırmada genel olarak diyabet hastaların sağlık inancı pozitif olarak değerlendirilmiştir. Konu ile ilgili diğer çalışmalar incelendiğinde; Sevinç ve arkadaşlarının (2012) çalışmasında diyabet hastalarının sağlık inancı pozitif, diğer çalışmalarda ise genel sağlık inancı negatif olarak değerlendirilmiştir (15-17). Bireylerin sağlık inançlarının olumlu sağlık davranışların başlatılmasında etkili olduğu, diyabet bakımı ile ilgili öz etkililiklerini iyileştirdiği ve metabolik kontrolün sağlanmasında önemli olduğu gösterilmiştir $(16,18,19)$. Hastaların sağlık inancı algılanan ciddiyet ve sağlıkla ilgili önerilen aktiviteler alt boyutunda yüksek bulunmuştur (Tablo 2). Bu bulgu hastaların hastalığını ciddi olarak algıladığını, hastalığın yönetimi ve komplikasyonların oluşmasını engellemeye yönelik davranışlarda bulunma motivasyonlarının yüksek olduğunu göstermektedir. Hastaların algılanan duyarlılık ve engeller alt boyutlarında düşük puan aldıkları belirlenmiștir. $\mathrm{Bu}$ bulgu ise hastaların kendilerini risk altında hissetme durumlarının ve duruma adapte olmada algıladıkları engellerin düşük olduğunu göstermektedir. Benzer olarak başka bir çalışmada da diyabet hastalarının en yüksek puan ortalamasının algılanan ciddiyet ve sağlıkla ilgili önerilen aktiviteler alt boyutunda olduğu ve en düşük ortalama puanın ise algilanan duyarlı1ık alt boyutundan aldığı belirlenmiştir (15). Orhan ve Karabacak' in (2016) çalışmasında da diyabet hastalarının ciddiyet algısının yüksek olduğu belirlenmiştir (20). Hastalıkla ilgili ciddiyet algısı yüksek olan diyabetli hastaların tedaviye uyumlarının ve metabolik kontrollerinin daha iyi olduğu belirlenmiştir (9). Bu nedenle pozitif sağlık inancının devamlılığının sağlanması önemlidir. 
Hastaların genel olarak diyabet tutumunun negatif olduğu belirlenmiştir (Tablo 2). $\mathrm{Bu}$ çalışmada hastaların diyabetin ciddiyetine olan inançları da yüksek bulunmuştur. Hastalığın ciddiyetine olan inancın ciddiyet tutumunu da etkilediği düşünülmektedir. Konu ile ilgili literatür incelemesinde farklı sonuçların olduğu görülmüştür. Örneğin Kara ve Çınar' In (2011) çalışmasında hastaların diyabet tutumları negatif iken (7) diğer çalışmalarda pozitif olduğu belirlenmiştir (21-25). Hastaların sadece diyabetin ciddiyeti alt boyutunda pozitif tutuma sahip oldukları görülmektedir (Tablo 2). Araştırmalara göre, olumlu tutuma sahip diyabetli bireylerde beslenme yönetimi, egzersiz, ilaç kullanımı, insülin enjeksiyonu, düzenli kan şekeri kontrolü gibi özyönetim davranışları, bakım yeteneği ve özbakımı, uzun dönemde remisyonu ve metabolik sonuçları olumlu etkilediği gözlemlenmiştir $(7,8,26)$. Bu nedenle negatif tutumların değiştirilmesi için uygun girişimlerin planlanması gerekmektedir.

Hastaların toplam sağlık inancı arttıkça kalça çevresi ortalamasının azaldığı ve HDL oranlarının arttığı tespit edilmiştir (Tablo 3). Bu çalışmada hastaların sağlıkla ilgili önerilen aktiviteleri gerçekleştirmeye yönelik inançlarının yüksek olmasının bu sonuca katkı sağladığı düşünülmektedir. Orhan ve Karabacak’ in (2016) çalışmasında, diyabetli hastalarda ciddiyet algısı arttıkça HDL düzeylerinin arttığı belirlenmiştir (21). Buna karşın Arısoy' un (2013) çalışmasında hastaların metabolik kontrol değerleri ile sağlık inançları arasında ilişki olmadığı saptanmıştır (27).

$\mathrm{Bu}$ araştırmada ilginç olarak hastaların pozitif diyabet tutumu arttıkça trigliserid düzeylerinin yükseldiği tespit edilmiştir (Tablo 3). Başka bir çalışmada diyabetli hastalarda pozitif tutum arttıkça açlık kan şekeri düzeyi ve diyastolik kan basıncı seviyesinin azaldığı negatif tutum arttıkça açlık kan şekeri, HDL kolesterol düzeylerinin ve diyastolik kan basıncı seviyesinin $\operatorname{arttığ1~belirlenmiştir~(7).~Bu~çalışmada~genel~olarak~}$ hastaların negatif tutuma sahip olduğu ve trigliserid düzeylerinin de çok yüksek olduğu belirlenmiştir.
Yüksek yağlı ve karbonhidrat ağırlıklı beslenme, hareketsizlik, alkol tüketimi, beta bloker, glukokortikoid ve östrojen kullanımı, hipotiroidi ve nefrotik sendrom gibi birçok faktör trigliserid düzeyini etkilemektedir (28). Bu çalışmada hastaların trigliserid değerlerindeki yüksekliğinin hastalık tutumundan ziyade diğer faktörlerden etkilendiği düşünülmektedir. $\mathrm{Bu}$ nedenle bu faktörlerinde araştırıldığı daha geniş örneklemler üzerinde araştırmaların yapılması gerektiği düşünülmektedir.

Araştırma sonucunda; araştırmaya katılan hastaların metabolik kontrol değerlerinin hedef değerlere göre iyi olmadığı belirlenmiştir. Diyabetli hastaların genel olarak pozitif sağlık inancına sahip olduğu ancak algılanan duyarlılık ve algılanan engellerde negatif sağlık inancı gösterdikleri tespit edilmiştir. Hastaların genel olarak diyabet tutumunun negatif olduğu sadece diyabetin ciddiyeti alt boyutunda pozitif tutuma sahip oldukları belirlenmiştir. Hastaların sağlık inancı ve diyabet tutumunun bazı metabolik kontrol değişkenleri etkilediği tespit edilmiştir. Diyabetlilerin hastalık yönetimi konusunda eğitilmesi ve sağlık inançları ile hastalığa karşı tutumlarının belirlenerek olumsuz inanç ve tutumların değiştirilmesi konusunda uygun girişimlerin yapılması önerilmektedir.

\section{KAYNAKLAR}

1. Olgun N. Diyabet (Tip 2) ve Bakım. in: Durna Z ed. Kronik Hastalıklar ve Bakım. 1. Baskı, Nobel Tıp Kitapevi, İstanbul. 2012: 291-332.

2. IDF Diabetes atlas. 7 th edition. Erişim tarihi: 09 Haziran 2017: http://www.diabetesatlas.org

3. Satman I, Omer B, TutuncuY, et al. TURDEP-II Study Group. Twelve-year Trends in the Prevalence and Risk Factors of Diabetes and Prediabetes in Turkish Adults. Europan Journal Epidemiology. 2013; 28(2): 169-80.

4. Kartal A, Ozsoy S. Validity and realibility study of the Turkish Version of Health Belief Model Scale 
in diabetic patients. Int J Nurs Stud. 2007; 44: 1447-58.

5. Gözüm S, Çapık C. Sağlık davranışlarının geliştirilmesinde bir rehber: sağlık inanç modeli. DEUHFED. 2014; 7(3): 230-7.

6. Champion LV, Skinner CS. The health belief model in: Glanz K, Rimer BK, Viswanath K. eds. Health behavior and health education theory, research and practice. Fourth Edition: Jones and Bartlett LLC, San Francisco. 2008: 31-44.

7. Kara K, Çınar S. Diyabet bakım profili ile metabolik kontrol değișkenleri arasındaki ilişki. Kafkas J Med Sci. 2011; 1(2): 57-63.

8. DanielM, Messer LC. Perception of disease severity and barriers to self care predict glysemic control in aboriginal persons with type 2 diabetes mellitus, Chronic Dis Can. 2002; 23 (4): 130-8.

9. Başkal N. Diabetes mellitus'ta hipoglisemi. Diyabet Forumu. 2002; 7(6): 42-5.

10. Tan MY. The relationship of health beliefs and complication prevention behaviors of Chinese individuals with type 2 diabetes mellitus. Diabetes Res Clin Pract. 2004; 66: 71-7.

11. Özcan H. Diyabetli hastalarda hastalarda uyumu etkileyen faktörlerin değerlendirilmesi. Doktora tezi. İstanbul Üniversitesi Sağlık Bilimleri Enstitüsü, İstanbul. 1999.

12. TEMD Diabetes mellitus ve komplikasyonlarının tanı, tedavi ve izlem kılavuzu-2017 Türkiye Endokrinoloji ve Metabolizma Derneği, 9. Bask1, Ankara, 2017. Erişim tarihi 09 Haziran 2017: http://www.turkendokrin.org/files/DIYABET2017_ web.pdf

13. American Diabetes Association Standards of Medical Care in Diabetes-2017. Diabetes Care. 2017; 40(1): 48-88.

14. Ali MK, Bullard KM, Saaddine JB, Cowie CC, Imperatore G, Gregg EW. Achievement of goals in
U.S. diabetes care, 1999-2010. N Engl J Med. $2013 ; 368: 1613-24$.

15. Agrali H, Akyar I. Older diabetic patients' attitudes and beliefs about health and illness. J Clin Nurs. 2013; 23: 3077-86.

16. Kartal A, Özsoy SA. Tip 2 diyabetli hastalarda planlı eğitim programının sağlık inancına ve metabolik kontrole etkisi. Hacettepe Üniversitesi Hemşirelik Fakültesi Dergisi. 2014; 2: 1-15.

17. Sevinç S, Fadıloğlu Ç, Katg1 A. Diyabetli bireylerde sağlık inancı glisemik kontrol ve komplikasyonlar. Türkiye Klinikleri Hemşirelik Bilimleri Dergisi. 2012; 4(1): 1-7.

18. Kashfi SM, Khani Jeihooni A, Rezaianzadeh A, Amini SH. The effect of health belief model educational program and jogging on control of sugar intype 2 diabetic patients. Iran Red Crescent Med J. 2012; 14(7): 442-6.

19. Akpunar D. Diyabet eğitiminin hastaların sağlık inancına, bilgi düzeyine ve diyabet yönetimine etkisi. Atatürk Üniversitesi Sağlık Bilimleri Enstitüsü, Halk Sağlığı Hemşireliği Anabilim Dalı Yüksek Lisans Tezi, Erzurum. 2012.

20. Orhan B, Karabacak BG. Tip 2 diyabetlilerde diyabete ilişkin bilişsel ve sosyal faktörler ve metabolik kontrol parametreleri arasındaki ilişki. Clin Exp Health Sci. 2016; 6(1): 1-8.

21. Kartal A, Çağırgan G, Tığlı H, Güngör Y, Karakuş N, Gelen M. Tip 2 diyabetli hastaların bakım ve tedaviye yönelik tutumları ve tutumu etkileyen faktörler. TAF Prev Med Bull. 2008; 7(3): 223-30.

22. Karaca Sivrikaya S, Erguney S. The effect of planned education given to the patients with type-2 diabetes mellitus on the attitudes, well-being and metabolic control variables of the patients. Diyabet, Obezite ve Hipertansiyonda Hemşirelik Forumu Dergisi. 2009; 1(2): 40-9.

23. Akgün Şahin Z. Tip 2 Diyabetli hastaların hastalığa karşı tutumu ve problem alanları arasındaki ilişki. ODÜ T1p Dergisi. 2015; 2: 134-8. 
24. Akaltun H, Ersin F. Evde Bakım hizmeti alan diyabetli hastaların diyabet tutum ve davranışlarının belirlenmesi. DEUHFED. 2016; 9(4): 126-33.

25. Vardar İnkaya B, Karadağ E. Tip 2 diyabetli bireylerin hastalıkları ve tedavilerine yönelik tutumlarını etkileyen faktörler. Diyabet, Obezite ve Hipertansiyonda Hemşirelik Forumu Dergisi. 2011; 3(1): 1-8.

26. Kueh YC, Morris T, Borkoles E, Shee H. Modelling of diabetes knowledge, attitudes, selfmanagement, and quality of life: a cross-sectional study with an Australian sample. Health Qual Life Outcomes. 2015; 13: 129-40.

27. Arısoy H. Yaşlı diyabet hastalarının hastalık ve sağlığa ilişkin tutumları. Hacettepe Üniversitesi Sağlık Bilimleri Enstitüsü Yüksek Lisans Tezi, Ankara. 2013.

28. Obezite, Lipid Metabolizması ve Hipertansiyon Çalışma Grubu, Lipid Metabolizma Bozuklukları Tanı ve Tedavi Kılavuzu. Türkiye Endokrinoloji ve Metabolizma Derneği. Ankara, 2016. Erişim tarihi: 18 Nisan 2017:

http://www.turkendokrin.org/files/LIPID_web.pdf 